\title{
IMPLEMENTASI PEMBELAJARAN BERBASIS BUDAYA DALAM MENINGKATKN PRESTASI BELAJAR SISWA PADA MATA PELAJARAN AKIDAH AKHLAK DI KELAS V MADRASAH IBTIDAIYAH NW LENDANG BATU
}

\author{
Saharudin, Sripa Surayya \\ Program Studi Pendidikan Guru Madrasah Ibtidaiyah \\ Fakultas Tarbiyah IAI Hamzanwadi NW Lombok Timur \\ e-mail: hardinsah123@gmail.com
}

\begin{abstract}
ABSTRAK: Penelitian ini bertujuan untuk mendeskripsikan, Strategi pelaksanaan pembelajaran berbasis budaya dan mendeskripsiskan implemntasi pembelajaran berbasis budaya, batasan istilah Penelitian ini strategi menggambar, motivasi dan penilaian dalam implementasi Pembelajaran Berbasis Budaya dalam meningkatkan prestasi belajar siswa pada mata pelajran Akidah Akhlak di kelas V Madrasah Ibtidaiyah NW Lendang Batu tahun ajaran 2018/2019. Penelitian ini menggunakan pendekatan kuantittatif dengan jenis deskriptif. Objek penelitian ini adalah Siswa kelas V MI NW Lendang Batu. Penelitian ini dilaksanakan di MI NW Lendang Batu, pada Teknik pengumpulan data yang digunakan adalah observasi, penilaian, dan dokumentasi. Instrumen utama adalah peneliti dengan mengunakan alat bantu berupa pedoman lembaran observasi, Penilaian, dan Dukumentasi. Data dianalisis dengan menggunakan penyajian data, dengan cara deskreptif dan kuantitatif dan penarikan kesimpulan. Hasil penelitian menunjukkan bahwa: pertama, dari segi Pelaksanaan pembelajaran berbasis budaya merupakan strategi yang tepat untuk pembelajaran akidah akhlak. Kedua, pembelajran berbasisis budaya dapat meningkatkan motivasi dan prestasi peserta didik.
\end{abstract}

Kata Kunci: Pembelajaran Berbasis Budaya, Prestasi Belajar

\section{PENDAHULUAN}

Salah satu masalah yang dihadapi dunia pendidikan dewasa ini adalah masalah lemahnya proses pembelajaran. Anak kurang didorong untuk mengembangkan kemampuan berpikir. Proses pembelajaran diarahkan kepada kemampuan anak untuk menghafal informasi, otak anak dipaksa untuk mengingat dan menimbun berbagai informasi tanpa di tuntut untuk memahami informasi yang diingatnya itu untuk menghubungkannya dengan kehidupan sehari-hari. Akibatnya ketika anak didik kita lulus dari sekolah, mereka pintar secara teoritis, tetapi mereka miskin aplikasi.
Pengembangan metodologi pendidikan agama islam, bisa saja berangkat dari realitas tuntutan dunia persekolah atau bisa juga tuntutan kehidupan masyarakat pada umumnya. Jika pendidikan agama islam hanya berkutat pada strategi-strategi lama yang sudah dianggap tradisional, maka kegiatan pendidikan agama islam akan berjalan ditempat. Oleh karena itu memperbaharui dan mengembangkan aspek metodologi dalam proses pendidikan agama islam, sangatlah mutlak diperlukan. A. Fatah Yasin, (Malang: 2008 : 194)

Pendidikan seharusnya menghasilkan SDM berkemauan dan berkemampuan untuk senantiasa meningkatkan kualitasnya secara terus menerus dan berkesinam- 
bungan. Sebagaimana dalam Undang-

Undang Republik Indonesia No 20 tahun 2003, tentang pendidikan nasional (Undang- Undang Sisdiknas), yang mengemukakan bahwa pendidikan nasional bertujuan mengembangkan potensi peserta didik agar menjadi manusia yang beriman dan bertakwa terhadap Tuhan yang Maha Esa, berakhlak mulia, sehat, berilmu, cakap, kreatif, mandiri, dan menjadi warga negara yang demokratis serta bertanggung jawab dalam rangka mencerdaskan kehidupan bangsa. E. Mulyasa, (Bandung: 2006: 7).

Karena pendidikan merupakan hak seluruh umat manusia. Pendidikan erat kaitannya dengan kehidupan manusia. Undang-Undang Republik Indonesia No. 20 Tahun 2003 tentang Sistem Pendidikan Nasional pada Bab I Ketentuan Umum pasal 1 ayat 16 menyebutkan bahwa:

"Pendidikan berbasis masyarakat adalah penyelenggaraan pendidikan berdasarkan kekhasan agama, sosial, budaya, aspirasi, dan potensi masyarakat sebagai perwujudan pendidikan dari, oleh, dan untuk masyarakat".

Karena berhasil atau tidaknya suatu pendidikan salah satunya adalah sangat ditentukan oleh kemampuan guru. Karena Guru merupakan komponen paling menentukan dalam sistem pendidikan secara keseluruhan, yang harus mendapat perhatian sentral, pertama dan utama. Guru memegang peran utama dalam pembangunan pendidikan, khususnya yang diselenggarakan secara formal di sekolah. Oleh karena itu, Guru harus pandai memilih strategi yang tepat dan sesuai dengan kebutuhan anak didik agar merasa senang dalam belajar, khususnya guru mata pelajaran aqidah akhlak, karena pelajaran aqidah akhlak merupakan pelajaran yang mengandung nilai-nilai yang terkait dengan perilaku kehidupan sehari-hari. Pendidikan agama islam dalam pelaksanaannya sangat membutuhkan adanya metodologi, baik yang menyangkut prinsip, asas, pendekatan, metode/strategi maupun teknik. Semua itu membutuhkan pengembangan agar sesuai dengan konteks kehidupan manusia yang selalu berubah, seiring dengan perubahan paradigma pendidikan pada umumnya.

Proses pembudayaan di sekolah adalah untuk pencapaian akademik siswa, untuk membudayakan siswa, pengetahuan ketrampilan dan tradisi yang ada dalam suatu komunitas budaya, serta untuk mengembangkan budaya dalam suatu komunitas melalui pencapaian akademik siswa. Karena pendidikan merupakan proses pembudayaan, dan pendidikan juga di pandang sebagai alat untuk perubahan budaya. Proses pembelajaran di sekolah merupakan proses pembudayaan yang formal atau proses akulturasi. Pendidikan 
menyebabkan terjadinya beragam perubahan dalam bidang social budaya, ekonomi, politik, dan agama. Pendidikan juga merupakan alat untuk konservasi budaya, transmisi, adopsi, dan pelestarian budaya, Pembelajaran berbasis budaya merupakan strategi penciptaan lingkungan belajar dan perencangan pengalaman belajar mengintregasikan budaya sebagai bagian dari proses pembelajaran. Pembelajaran berbasis budaya dilandaskan pada pengakuan terhadap budaya sebagai bagian yang fundamental (mendasar dan penting) bagi pendidikan, ekspresi dan komunikasi suatu gagasin, dan perkembangan pengetahuan.

Pembelajaran berbasis budaya sebagai strategi pembelajaran mendorong terjadinya proses imaginative, metaforik, berpikir kreatif, dan juga sadar budaya. Pembelajaran berbasis budaya dapat dibedakan menjadi tiga macam, yaitu belajar tentang budaya, belajar dengan budaya, dan belajar melalui budaya. Begitu juga dalam pendidikan karakter di sekolah, semua komponen (stakeholders) harus dilibatkan, termasuk komponen-komponen pendidikan itu sendiri, yaitu isi kurikulum, proses pembelajaran dan penilaian, kualitas hubungan, penanganan atau pengelolaan mata pelajaran, pengelolaan sekolah, pelaksanaan aktivitas atau kegiatan kokurikuler, pemberdayaan sarana prasarana, pembiayaan, dan etos kerja seluruh warga dan lingkungan sekolah.
Dalam penelitian ini penulis mengambil mata pelajaranan aqidah akhlak tentang akhlak terpuji, karena krisis multidimensi yang melanda bangsa kita sudah dalam batas yang sangat memprihatinkan terutama krisis moral di kalangan generasi muda, karena tidak lagi menggunakan budaya dan agama, keperibadian bangsa sendiri lebih cendrung meniru budaya negara barat, dengan demikian pendidik harus lebih keras lagi untuk membangun generasi muda dengan landasan iman dan moral yang kokoh agar eksistensi bangsa ini biar lebih terjamin, karena eksistensi suatu bangsa hanyalah karena akhlaknya, bila akhlaknya bobrok maka binasalah mereka. Untuk itu dengan materi aqidah akhlak dapat menumbuh kembangkan akidah pada peserta didik melalui pemberian, pemupukan, dan pengembangan pengetahuan, penghayatan, pengamalan, pembiasaan, serta pengalaman peserta didik tentang agama Islam sehingga menjadi manusia muslim yang terus berkembang keimanan dan ketakwaannya kepada Allah SWT. Dan mewujudkan manuasia Indonesia yang taat beragama dan berakhlak mulia yaitu manusia yang berpengetahuan, rajin beribadah, cerdas, produktif, jujur, adil, etis, berdisiplin, bertoleransi (tasamuh), menjaga keharmonisan secara personal dan sosial serta mengembangkan budaya agama dalam komunitas sekolah. Tetapi 
apabila dalam pembelajaran aqidah akhlak masih menggunakan strategi kuno, seperti ceramah, hafalan dan tanya jawab maka akan menjadikan peserta didik bosan dan kurang bersemangat untuk belajar.

Madrasah Ibtidaiyah NW Lendang Batu adalah merupakan salah satu MI NW yang berlokasi di Dusun Lendang Batu Desa Sukamulia Timur Kecamatan Sukamulia Kabupaten Lombok Timur. Sekolah ini termasuk sekolah sebanding dengan sekolah- sekolah SD yang lain, Sekolah ini tempatnya sekitar seratus meter dari jalan raya dan berada di tengah perkampungan, mempunyai murid yang cukup banyak juga adanya pengakuan dari masyarakat, sehingga sekolah ini mampu menarik minat para penduduk setempat dan sekitarnya untuk menyekolahkan putra-putrinya di sekolah tersebut. Oleh karena itu perbaikan dalam perencanaan, proses, dan evaluasi pembelajaran harus selalu ditingkatkan menjadi lebih baik dan lebih baik lagi, sehingga mampu mencetak output sesuai dengan harapan.

Dalam proses mengajar-belajar peranan guru tentu sangat penting. Segala tindakannya akan diwarnai oleh kepribadiannya. Apakah ia bersifat kritis terhadap dirinya untuk meningkatkan mutunya sebagai pendidik, apakah ia terbuka bagi ideide baru dan bersedia mengadakan percobaan, apakah ia suka akan anakanak dan berusaha mendekatkan diri kepada mereka untuk memahaminya, apakah ia menerima pribadi anak menurut keadaan masing-masing dan senantiasa memberi semangat belajar atau menumpuk rasa percaya akan diri sendiri. Banyak lagi hal lain yang turut membantu menentukan mutu dan suasana belajar yang dipengaruhi oleh pribadi guru. Nasution, (2005: 50).

Pembelajaran di MI NW Lendang Batu ini sebagaian besar masih menggunakan strategi lama yakni ceramah, hafalan dan terkadang Tanya jawab, jika hal ini berlangsung terus-menerus maka bisa menjadikan siswa bosan dalam belajar, jika tidak ada variasi metode dan strategi maka siswa akan merasa jenuh menerima pelajaran, dan hal inilah yang dapat menyebabkan siswa tidak konsentrasi, mengantuk, dan bahkan tidur di dalam kelas saat Kegiatan Belajar Mengajar masih berlangsung, kondisi demikian harus segera diatasi dengan perubahan dalam mengajar, jika dulu siswa hanya datang, duduk, diam mendengarkan dan mencatat seperti yang ada dipapan tulis, maka saat inilah siswa harus benarbenar dilibatkan dalam proses pembelajaran.

Berdasarkan latar belakang di atas perlu kiranya diadakan suatu penelitian pendidikan, dalam hal ini penulis akan mengangkat Judul "implementasi pembelajaran berbasis budaya dalam meningkatkan prestasi belajar siswa pada mata pelajaran akidah akhlak di kelas $\mathrm{V}$ Madrasah Ibtidaiyah NW Lendang Batu tahun Pelajaran 2018/2019”. 


\section{KAJIAN TEORI}

\section{A. Pengertian Pembelajaran Berbasis Budaya}

Proses belajar dapat terjadi di mana saja sepanjang hayat. Sekolah merupakan salah satu tempat proses belajar terjadi. Sekolah merupakan tempat kebudayaan karena pada dasarnya proses belajar merupakan proses pembudayaan. Dalam hal ini, proses pembudayaan di sekolah adalah untuk pencapaian akademik siswa. Untuk membudayakan sikaf, pengetahuan, keterampilan dan tradisi yang ada dalam suatu komunitas budaya, serta untuk mengembangkan budaya dalam suatu komunitas melalui pencapaian akademik siswa.

Dengan demikian, belajar budaya merupakan proses belajar satu kesatuan yang utuh dan menyeluruh dari beragam perwujudan yang di hasilkan dan atau berlaku dalam suatu komunitas. Mata pelajaran yang disuguhkan dalam kurikulum dan diajarkan kepada siswa di sekolah, sebagai pola fikir ilmiah, merupakan salah satu perwujudan budaya, sebagai bagian dari budaya. bahkan, seorang ahli menyatakan bahwa kemajuan teknologi dari ilmu pengetahuan mencerminkan pencapaian upaya manusia pada saat tertentu berbasiskan pada budaya saat itu.

Jadi Pembelajaran berbasis budaya merupakan strategi penciptaan lingkungan belajar dan perencangan pengalaman belajar mengintregasikan budaya sebagai bagian dari proses pembelajaran. Pembelajaran berbasis budaya dilandaskan pada pengakuan terhadap budaya sebagai bagian yang fundamental (mendasar dan penting) bagi pendidikan, ekspresi dan komunikasi suatu gagasan, dan perkembangan pengetahuan. Pembelajaran berbasis budaya sebagai strategi pembelajaran mendorong terjadinya proses imaginative, metaforik, berpikir kreatif, dan juga sadar budaya. Partisipasi dengan dan melalui berbagai ragam bentuk perwujudan budaya memberikan kebebasan bagi siswa untuk belajar dan menggali prinsif aprinsif dalam suatu mata pelajaran, menemukan hala hal yang bermakna di sekelilingnya, dan mendorongnya untuk membuka dan menemukan hal hal yang baru di dunia baru. Suprayekti dkk, (2009 : 4.12).

Proses belajar dalam pembelajaran berbasis budaya berfokus pada hal- hal berikut:

(1) Strategi atau cara agar siswa dapat melihat keterhubungan antar konsef/ prinsif dalam bidang ilmunya, dengan budaya, dalam beragam konteks yang baru, dan dalam konteks komunitas budayanya.

(2) Strategi atau cara agar siswa memperoleh pemahaman terpadu tentang bidang ilmu dan budaya sebagai landasan untuk berfikir kritis, 
menyelesaikan beragam permasalahan dalam konteks komunitas budaya, serta mengambil keputusan yang sahihberdasarkan kaidah keilmuan.

(3) Strategi atau cara agar semua siswa dapat berpartisipasi aktif, senang, dan bangga untuk belajar bidang ilmu dalam pembelajaran berbasis budaya.

(4) Strategi atau cara agar siswa dapat menciptakan makna berdasarkan pengetahuan dan pengalaman awal yang dimiliki, melalui beragam interaksi aktif dengan siswa lain, guru, tokoh, dan juga dengan materi atau contoh konkret.

(5) Straegi atau cara agar siswa dapat memperoleh pengalaman bahwa ada kaidah keilmuan dalam kehidupan sehari hari siswa dan konteks komunitas budayanya, juga ada budaya dalam konteks bidang ilmu, dan bahwa kaidah keilmuan adalah bagian dari budaya mereka.

(6) Strategi atau cara agar siswa dapat memperoleh pemahaman yang terintegrasi dan keterampilan ilmiah (scientific inquiry skill) dalam mempersepsikan segala sesuatu di sekelilingnya, termasuk dalam budaya dan ragam perwujudan budaya. Suprayekti dkk, (2009: 4.22).

\section{B. Prestasi Belajar}

Prestasi belajar adalah sebuah kalimat yang terdiri dari dua kata yaitu prestasi dan belajar. Antara kata prestasi dan belajar mempunyai arti yang berbeda. Oleh karena itu, sebelum pengertian prestasi belajar, ada baiknya pembahasan ini diarahkan pada masing-masing permasalahan terlebih dahulu untuk mendapatkan pemahaman lebih jauh mengenai makna kata prestasi dan belajar. Hal ini juga untuk memudahkan dalam memahami lebih mendalam tentang pengertian prestasi belajar itu sendiri. Di bawah ini akan dikemukakan beberapa pengertian prestasi dan belajar menurut para ahli:

"Prestasi adalah hasil dari suatu kegiatan yang telah dikerjakan, diciptakan baik secara individu maupun secara kelompok. prestasi tidak akan pernah dihasilkan selama seseorang tidak melakukan kegitan" Hamdani. (Pustaka Setia Bandung, 2011: 137 ).

Sedangkan menurut Qahar dalam jamarah (Hamdani 2011 : 137)" bahwa prestasi ada lah apa yang telah dapat diciptakan, hasil pekerjaan, hasil yang menyenangkan hati yang diperoleh dengan jalan keuletan kerja".

Dari pengertian yang dikemukakan tersebut di atas, jelas terlihat perbedaan pada kata-kata tertentu sebagai penekanan, namun intinya sama yaitu hasil yang dicapai dari suatu kegiatan. Untuk itu, dapat dipahami bahwa prestasi adalah hasil dari suatu kegiatan yang telah dikerjakan, diciptakan, yang menyenangkan hati, yang diperoleh dengan jalan keuletan kerja, baik secara individual maupun secara kelompok 
dalam bidang kegiatan tertentu.

Beberapa faktor yang mempengaruhi prestasi belajar antara lain:

a) Kecerdasan/ intelegensi

Kecerdasan adalah kemampuan belajar disertai kecakapan untuk menyesuaikan diri dengan keadaan yang dihadapinya. Kemampuan ini sangat ditentukan oleh tinggi rendahnya intelegensi yang normal selalu menunjukkan kecakapan sesuai dengan tingkat perkembangan sebaya. Adakalanya perkembangan ini ditandai oleh Kemajuan-kemajuan yang berbeda antara satu anak dengan anak yang lainnya, sehingga seseorang anak pada usia tertentu sudah memiliki tingkat kecerdasan yang lebih tinggi dibandingkan dengan kawan sebayanya. Oleh karena itu jelas bahwa faktor intelegensi merupakan suatu hal yang tidak diabaikan dalam kegiatan belajar mengajar. Slameto (1995:56 (dalam Hamdani 2011:139) mengatakan bahwa "tingkat intelegensi yang tinggi akan lebih berhasil daripada yang mempunyai tingkat intelegensi yang rendah."

b) Faktor Jasmaniah atau Faktor fisiolagis

Faktor Jasmaniah atau Fisiologis pad umunya sangat berpengaruh terhadap kemampuan belajar seseorang. Uzer dan Lilis mengatakan bahwa faktor jasmaniah, yaitu panca indra yang tidak berpungsi sebagaimana mestinya, seperti mengalami sakit, cacat tubuh atau perkembangan yang tidak sempurna, berpunsi kelenjar yang membawa kelainan tingkah laku (Hamdani $2007: 140)$

c) Sikap

Hamdani, (2007 : 140) Sikap yaitu "suatu kecendrungan untuk mereaksi terhadap suatu hal, orang atau benda dengan suka, tidak suka atau acuh tak acuh. Sikap seseorang dapat dipengaruhi, kebiasaan dan keyakinan" (Hamdani $2007: 140)$

d) Bakat

Bakat adalah kemampuan tertentu yang telah dimiliki seseorang sebagai kecakapan pembawaan. Ungkapan ini sesuai dengan apa yang dikemukakan oleh Ngalim Purwanto (1986:28), dalam Hamdan 2007:141) bahwa "bakat dalam hal ini lebih dekat pengertiannya dengan kata attitude yang berarti kecakapan, yaitu mengenai kesanggupan-kesanggupan”.

Dari pendapat di atas jelaslah bahwa tumbuhnya keahlian tertentu pada seseorang sangat ditentukan oleh bakat yang dimilikinya sehubungan dengan bakat ini dapat mempunyai tinggi rendahnya prestasi belajar bidangbidang studi tertentu.

e) Minat

Minat adalah kecenderungan yang tetap untuk memperhatikan dan mengenai beberapa kegiatan. Kegiatan yang dimiliki seseorang diperhatikan terus menerus yang disertai dengan rasa sayang.

Dengan ini jelaslah bahwa minat 
besar pengaruhnya terhadap belajar atau kegiatan. Bahkan pelajaran yang menarik minat siswa lebih mudah dipelajari dan disimpan karena minat menambah kegiatan belajar. Minat belajar yang telah dimiliki siswa merupakan salah satu faktor yang dapat mempengaruhi hasil belajarnya. Apabila seseorang mempunyai minat yang tinggi terhadap sesuatu hal maka akan terus berusaha untuk melakukan sehingga apa yang diinginkannya dapat tercapai sesuai dengan keinginannya.

f) Motivasi

"Motivasi adalah segala ssuatu yang mendorong seseorang untuk melakukan sesuatu." Ngalim purwanto dalm Hamdani, ( $2007:$ 142).

\section{Pembelajaran Akidah Akhlak}

Aqidah dan akhlak terdiri dari dua kata, aqidah dan akhlak, berikut ini pengertian akidah akhlak

\section{a. Pengertian Aqidah}

Aqidah adalah bentuk masdar dari kata ('aqoda, ya'qidu, 'aqdan- 'aqidatan) yang berarti simpulan, ikatan, sangkutan, perjanjian dan kokoh. Sedang secara teknis aqidah berarti iman, kepercayaan dan keyakinan. Dan tumbuhnya kepercayaan tentunya di dalam hati, sehingga yang dimaksud aqidah adalah kepercayaan yang menghujam atau tersimpul di dalam hati. Tadjab dkk (dalam abdittama 1994 :241). Sedangkan menurut istilah aqidah adalah hal-hal yang wajib dibenarkan oleh hati dan jiwa merasa tentram kepadanya, sehingga menjadi keyakinan kukuh yang tidak tercampur oleh keraguan. Abdullah (Bogor pustaka ibdu katsir 2005 :28)

\section{b. Pengertian Akhlak}

Sedang pengertian akhlak secara etimologi berasal dari kata "Khuluq" dan jama'nya "Akhlaq", yang berarti budi pekerti, etika, moral. Demikian pula kata "Khuluq" mempunyai kesesuaian dengan "Khilqun", hanya saja khuluq merupakan perangai manusia dari dalam diri (ruhaniah) sedang khilqun merupakan perangai manusia dari luar (jasmani).

Menurut Ahmad Amin, Akhlak ialah kehendak yang dibiasakan. Artinya kehendak itu bila membiasakan sesuatu, maka kebiasaan itulah yang dinamakan akhlak. Dalam penjelasan beliau, kehendak ialah ketentuan dari beberapa keinginan sesudah bimbang, sedangkan kebiasaan ialah perbuatan yang diulang-ulang sehingga mudah dikerjakan. Jika apa yang bernama kehendak itu dikerjakan berulangkali sehingga menjadi kebiasaan, maka itulah yang kemudian berproses menjadi akhlak. (Tim Dosen Agama Islam)

Sedangkan Pembelajaran adalah suatu kombinasi yang tersusun meliputi unsur-unsur manusiawai, material, fasilitas, perlengkapan, dan prosedur yang saling mempengaruhi mencapai tujuan pembelajaran. Manusia terlibat dalam sistem pengajaran terdiri dari siswa, guru, 
dan tenaga lainnya, misalnya tenaga laboratorium. Material, meliputi bukubuku, papan tulis, dan lapur, gambargrafi, slide dan film, audio dan video tape. Fasilitas dan perlengkapan, terdiri dari ruangan kelas, perlengkapan audio visual, juga komputer. Prosedur, meliputi jadwal dan metode penyampaian informasi, praktik, belajar, ujian, dan sebagainya Oemar hamalik (Jakarta : 2007 : 57). Pembelajaran adalah upaya guru untuk mengorganisasikannya lingkungan untuk menciptakan kondisi belajar bagi peserta didik.

Sesuai dengan pendapat diatas dapat penulis simpulkan pembelajaran aqidah akhlak adalah segala sesuatu yang yang di setting guru sebagai upaya menyiapkan peserta didik untuk mengenal, memahami, menghayati dan mengimani Allah SWT dan merealisasikannya dalam perilaku akhlak mulia dalam kehidupan sehari-hari berdasarkan Qur'an dan Hadits melalui kegiatan bimbingan, pengajaran, latihan, serta penggunaan pengalaman.

\section{METODE PENELITIAN}

\section{Pendekatan Penelitian}

Dalam pelaksanaan suatu penelitian untuk mencapai hasil yang diinginkan sebagai hasil ilmiah dalam melakukan penelitian diperlukan sebuah pendekatan . penelitian, dalam hal ini peneliti menggunakan Pendekatan penelitian kuantitatif yang berjudul "implementasi pembelajaran berbasis budaya dalam meningkatkan prestasi belajar siswa pada mata pelajaran akidah akhlak di kelas V MI NW Lendang batu tahun pelajaran 2018/2019.

Penelitian ini tergolong pengertian kuantitatif deskriptif. Dharminto, (2010:6), menerangkan penelitian deskriptif melakukan analisis sampai taraf deskripsi yaitu menganalisis fakta dan menyajikan secara sistematis sehingga dapat lebih mudah untuk dipahami dan disimpulkan. Sejalan dengan Dharmintho, dalam Sukardi (2008: 157) menerangkan penelitian deskriptif merupakan metode penelitian yang berusaha menggambarkan dan menginterpretasi objek sesuai dengan apa adanya. Sukardi sendiri menambahkan, penelitian deskriptif sering disebut penelitian non eksperimen karena pada penelitian ini tidak melakukan kontrol dan memanipulasi variabel penelitian. Penelitian ini menggunakan pendekatan kuantitatif deskriptif karena peneliti bertujuan untuk meneliti kemampuan siswa, dengan penghitungan angka (nilai siswa) dan juga deskripsi kemampuan siswa melalui pengamatan. Data yang diperoleh dalam penelitian ini akan diolah secara statistik dan dideskripsikan sebagai penjelasan data.

\section{Populasi dan Sampel Penelitian}

\section{a. Populasi Penelitian}

Populasi berasal dari bahasa Inggris population, yang berarti jumlah penduduk. oleh karena itu apa bila disebutkan kata 
populasi, orang kebanyakan menghubungkannya dengan masalah-masalah kependudukan. kemudian pada perkembangan selanjutnya, kata populasi menjadi amat populer, dan digunakan diberbagai disiplin ilmu.

Dalam metode penelitian kata populasi amat populer, digunakan untuk menyebutkan serumpun atau sekelompok objek yang menjadi sasaran penelitian. Pada populasi penelitian ini peneliti mengambil siswa kelas $\mathrm{V}$ sekolah Madrasah Ibtidaiyah NW Lendang Batu semester 1 tahun ajaran 2018/2019.

\section{b. Sempel Penelitian}

Sampel penelitian merupakan suatu faktor penting yang perlu diperhatikan dalam penelitian yang kita lakukan, sempel penelitian mencerminkan dan menentukan seberapa jauh sempel tersebut bermanfaat dalam membuat kesimpulan penelitian, $\mathrm{H}$ Punaji styosari, (2010:189).

Sugiyanto, (2008:218) menegaskan Probability Sampling adalah teknik pengambilan sampel yang memberikan peluang yang sama bagi setiap unsur (anggota) populasi untuk dipilih menjadi anggota sampel. Sedangkan Nonprobability Sampling adalah teknik pengambilan sampel yang tidak memberi peluang atau kesempatan sama bagi setiap unsur atau anggota populasi untuk dipilih menjadi sampel. Teknik sampel ini meliputi sampling sistematis, kuota, aksidental, purposive, jenuh, dan snowball.

Dalam penelitian ini, Karena jumlah populasi hanya 16 siswa, peneliti menggunakan seluruh populasi sebagai objek penelitian atau seluruh populasi menjadi sampel (sampel jenuh). Sampel jenuh adalah teknik penentuan sampel bila semua anggota populasi dijadikan sampel (Tim admin, 2011). Peneliti memilih semua populasi menjadi sampel karena jumlah populasi yang relatif kecil serta peneliti menginginkan generalisasi dengan kesalahan yang sangat kecil.

\section{Instrumen Pengumpulan Data}

a. Instrument implementasi pembelajaran berbasisi budaya dengan menggunakan lembaran observasi.

b. Dan instrument prestasi belajar diambil dari hasil belajar mata pelajaran akidah ahlak siswa.

\section{Tehnik Pengumpulan Data}

a. Observasi

Observasi atau pengamatan adalah kegiatan keseharian manusia dengan menggunakan pancaindra mata sebagai alat bantu utamanya selain pancaindra lainnya seperti telinga, penciuman, mulut, dan kulit. Oleh karena itu, observasi adalah kemampuan seseorang untuk menggunakan pengamatannya melalui hasil kerja pancaindra mata serta dibantu oleh pancaindra lainnya. Di dalam pembahasan ini kata observasi dan pengamatan digunakan secara bergantian . 
Dari pemahaman observasi atau pengamatan di atas, sesungguhnya yang dimaksud dengan obsevasi adalah metode pengumpulan data yang digunakan untuk menghimpun data penelitian, data-data penelitian tersebut dapat diamati oleh peneliti. Dalam arti bahwa data tersebut dihimpun melalui pengamatan peneliti melalui penggunaan pancaindra.

Suatu kegiatan pengamatan baru dikategorikan sebagai kegiatan pengumpulan data penelitian apabila memiliki kriteria sebagai berikut:

1). Pengamatan digunakan dalam penelitian dan telah direncanakan secara sistimatik.

2). pengamatan harus berkaitan dengan tujuan penelitian yang telah di tetapkan.

3). pengamatan tersebut dicatat secara sistimatik dan dihubungkan dengan proposisi umum dan bukan dipaparkan sebagai sesuatu yang hanya menarik perhatian.

4). Pengamatan dapat dicek dan dikontrol mengenai validitas dan reliabilitasnya.

\section{b. Penilaian}

Seperti penilaian pengamatan, penilaian hasil belajar siswa juga melalui penskoran menggunakan rating scale yang mencakup aspek-aspek penilaian hasil belajar seperti, aspek kesesuaian dengan perintah yang diberikan, hal ini berpengaruh pada bagaimana siswa menangkap perintah dari peneliti atau guru. Data penilaian hasil belajar siswa dijumlahkan skornya dan menjadi skor hasil belajar siswa untuk mengetahui tingkat kemampuan siswa. Nilai akhir siswa diperoleh dari skor pengamatan dijumlahkan dengan skor hasil, nilai akhir siswa disebut sebagai tingkat prestasi siswa.

c. Dokumentasi

Dokumentasi dalam penelitian ini digunakan untuk memperoleh data namanama siswa sebagai populasi dan sampel, data-data berupa data nilai siswa sebelum dan sesudah menggunakan pembelajaran berbasis budaya, dan lembar penilaian observasi siswa.

Dokumentasi juga digunakan untuk mendapatkan hasil belajar siswa sebelum dilaksanakannya proses pembelajaran berbasis budaya dengan tujuan untuk mengetahui prestasi awal siswa, serta sebagai pembanding dengan prestasi belajar setelah dilaksanakannya pembelajaran berbasis budaya. prestasi belajar siswa sebelum proses pembelajaran juga digunakan untuk mengetahui perubahan prestasi siswa serta tingkat keberhasilan pelaksanaan pembelajaran berbasis budaya.

\section{Teknik Analisis Data}

Pengolahan data adalah kegiatan lanjutan setelah pengumpulan data di laksanakan" H. M Burhan Bungin 
(2005:164). Pada Penelitian Kuantitatif, pengolahan Data secara umum dilaksanakan melalui tahap memeriksa proses pemberian identitas Metode analisis data yang digunakan dalam penelitian ini adalah dengan menggunakan deskriptif kuantitatif.

a. Deskripsi Data

Data yang diperoleh merupakan data yang berhubungan dengan kemampuan siswa dalam menggambar (kalikatur), seperti nilai tes praktek, nilai pengamatan pada saat dilaksanakannya proses pembelajaran, dan data dalam bentuk prestasi belajar serta dokumen-dokumen yang berhubungan dengan penelitian.

b. Analisis Data

Penyajian data digunakan untuk menyajikan data-data yang telah diperoleh dan untuk memudahkan dalam melaporkan data hasil penelitian. Dalam penelitian ini peneliti akan menyajikan data secara deskriptif dan dengan menggunakan tabel nilai pengamatan siswa dan tabel nilai prestasi siswa. H. Punaji (2010:209) "Analisis data adalah upaya yang dilakukan oleh guru yang berperan sebagai peneliti untuk merangkum secara akurat data yang telah dikumpulkan dalam bentuk yang dapat dipercaya dan benar". Analisis data merupakan pekerjaan yang amat kritis dalam proses penelitian, peneliti harus secara cermat menentukan pola analisis bagi data penelitiannya. Model analisis mana yang dipilih, apakah analisis statistik atau nonstatistik.

Analisis statistik dipakai apabila peneliti berurusan dengan data yang berupa angka-angka (kuantitatif) atau data yang dikuantifikasinya. Analisis tes hasil belajar peserta didik sehingga memperoleh nilai rata-rata, dengan menggunakan rumus rata-rata (mean):

$$
\mathrm{X}=\frac{\sum \mathrm{x}}{\mathrm{n}}-
$$

Keterangan:

$$
\begin{aligned}
& \overline{\mathrm{X}}=\text { Nilai rata-rata } \\
& \sum \mathrm{x}=\text { Jumlah nilai semua siswa } \\
& \mathrm{n}=\text { Jumlah siswa }
\end{aligned}
$$

Peserta didik yang nilainya kurang dari standar $\mathrm{kkm}$ yang telah ditentukan dinyatakan mengalami kesulitan belajar dan peserta didik yang memiliki nilai lebih atau sama dengan standar KKM dinyatakan telah tuntas belajar atau berhasil. Untuk menghitung hasil ketuntasan belajar secara klasikal digunakan rumus:

$$
\mathrm{P}=\frac{\sum \text { Siswa yang tuntas belajar } \mathrm{X}}{\sum \text { Jumlah siswa }} 100
$$

Ketuntasan klasikal dinyatakan berhasil jika persentase peserta didik mendapatkan nilai $\geq 75$ sedangkan indikator ketuntasan aktivitas siswa dan guru adalah apabila aktivitas siswa aktif dan aktivitas guru baik. 
HASIL DAN PEMBAHASAN

\section{Hasil Penelitan Secara Deskriptif}

Data dari penelitian yang berjudul, "mplementasi Pembelajaran Berbasis Budaya dalam meningkatkan prestasi belajar siswa Kelas V MI NW Lendang Batu pada Mata Pelajaran Akidah Akhlak tahun ajaran 2018/2019”, ini diperoleh dengan melakukan pengamatan serta pembelajaran yang dilaksanakan pada hari Jumat 30 Oktober 2018. Data yang diperoleh berupa data hasil pengamatan dan data belajar siswa dalam bentuk gambar Kalikatur. Data-data tersebut akan dipaparkan dalam bentuk deskripsi dan tabel data. Deskripsi data merupakan penggambaran data yang diperoleh peneliti untuk menggambarkan kondisi objek yang diteliti, sehingga lebih mudah dipahami.

\section{Deskripsi Data Hasil Pengamatan}

Dari hasil pengamatan strategi pelaksanaan pembelajaran terhadap siswa kelas V MI NW Lendang Batu, peneliti menggambarkan data pengamatan dengan mengamati beberapa aspek, seperti strategi Pelaksanaan Pembuatan gambar kalikatur dan motivasi atau kesungguhan siswa dalam pelaksanaan pembelajaran. Pengamatan dilakukan menggunakan teknik penskoran rating scale.

Siswa kelas Kelas V MI NW Lendang Batu berjumlah 16 siswa, sebagian besar sudah memenuhi kriteria baik dalam penilaian pengamatan strategi pelaksanaan menggambar kalikatur. Siswa telah memenuhi skor yang tinggi dalam penilaian pengamatan pelaksanaan.

Dapat disimpulkan bahwa siswa sudah melaksanakan kegiatan pembelajaran akidah akhlak dengan cara menggabar kalikatur dengan baik, siswa telah mempunyai motivasi yang tinggi dalam melaksanakan tugasnya untuk menggambar. Meskipun ada dua siswa yang tidak melaksanakannya secara sungguhsungguh karena mengabaikan pernyataan yang diajukan guru. Siswa kelas V MI NW Lendang Batu juga sudah mengenal cara menggambar kalikatur sesuai dengan pelajaran akidah ahlak sub sifat tawakkal, adil dan bijaksana sebagai budaya agama dan akan berusaha melestarikan dengan prilaku dalam kehidupan sehari-hari. Aspek-aspek pengamatan dalam penelitian ini antara lain, (1) Strategi siswa dalam pelaksanaan menggambar kalikatur, (2) Motivasi dan kesungguhan siswa dalam pelaksanaan menggambar, (3) Kelengkapan alat-alat untuk menggambar (pensil dan buku gambar).

\section{Deskripsi Data Prestasi Siswa}

Untuk penilaian prestasi siswa dalam menggambar kalikatur dalam pelajaran akidah akhlak sub tanggung jawab, adil, dan bijak sana, peneliti juga menggunakan kriteria penilaian dengan dua aspek seperti.

a. Kesesuaian dengan perintah,

b. Kesesuaian gambar dengan pemaparan 
siswa. Aspek-aspek penilaian praktek sebagai berikut:

1). Kesesuaian dengan materi

Siswa telah melaksanakan pelaksanaan pembuatan gambar kalikatur dengan hasil yang sesuai dengan materi. Gambar yang dibuat merupakan gambar yang menerangkan tentang tanggung jawab, adil dan bijaksana sesuai dengan materi pelajaran akidah akhlak, sub tanggung jawab , adil, dan bijaksana yang terjadi baik dilingkungan sekolah maupun di lingkungan luar sekolah. Namun, karena obyek peneliti adalah siswa kelas $\mathrm{V}$, gambar kalikatur yang di hasilkan tidak sama persis dengan gambar kalikatur yang dibuat oleh para ahli gambar namun dapat dimengerti oleh peneliti.

2). Kesesuaian gambar dengan pemaparan siswa

Setelah siswa diperintahkan untuk menggambar tentang sikap tanggung jawab, adil, dan bijaksana baik prilaku di lingkungan sekolah sekolah maupun diluar sekolah, gambar yang dihasilkan langsung dipaparkan arti gambar yang sesuai dengan perintah, baik yang digambarkan sesuai dengan lingkungan sekolah ataupun dilingkungan luar sekolah.

3) Nilai Akhir

Nilai akhir pada penelitian ini adalah nilai pengamatan ditambahkan dengan nilai hasil gambar siswa dibagi dua Dari penilaian tersebut diperoleh tabel data sebagai berikut:

Tabel 4.4. Hasil observasi

\begin{tabular}{|c|c|c|c|}
\hline Nomor & Skor Pengamatan & Jumlah Siswa & Nilai \\
\hline 1 & $\geq 70$ & 1 & $\geq 70$ \\
\hline 2 & $\geq 75$ & 5 & $\geq 375$ \\
\hline 3 & $\geq 80$ & 3 & $\geq 240$ \\
\hline 4 & $\geq 85$ & 3 & $\geq 255$ \\
\hline 5 & $\geq 90$ & 4 & $\geq 360$ \\
\hline & $\sum \times 400$ & $\mathrm{n} 16$ & $\overline{\mathrm{x}} \geq 1300$ \\
\hline
\end{tabular}

Keterangan:

1) Yang mendapat skor pengamatan $\geq 70$ adalah satu Peserta didik

2) Yang mendapat skor pengamatan $\geq 75$ adalah lima Peserta didik

3) Yang mendapat skor pengamatan $\geq 80$ adalah tiga Peserta didik

4) Yang mendapat skor pengamatan $\geq 85$ adalah tiga Peserta didik

5) Yang mendapat skor pengamatan $\geq 90$ adalah empat Peserta didik

Jumlah siswa yang diamati adala 16 siswa. Dalam data skor pengamatan diketahui jumlah siswa yang diamati ada 16 siswa, dengan nilai pengamatan terendah 70 skor diperoleh satu peserta didik dan tertinggi 90 skor diperoleh empat peserta didik.

Skor penilaian prestasi peserta didik

Tabel 4.5. Penilaian Prestasi

\begin{tabular}{|c|c|c|c|}
\hline No & $\begin{array}{c}\text { Skor } \\
\text { prestasi }\end{array}$ & $\begin{array}{c}\text { Jumlah } \\
\text { siswa }\end{array}$ & Nilai \\
\hline 1 & $\geq 70$ & 1 & $\geq 70$ \\
\hline 2 & $\geq 75$ & 3 & $\geq 225$ \\
\hline 3 & $\geq 80$ & 3 & $\geq 240$ \\
\hline 4 & $\geq 85$ & 5 & $\geq 425$ \\
\hline 5 & $\geq 90$ & 4 & $\geq 360$ \\
\hline & $\sum \times \geq 400$ & $\mathrm{n} 16$ & $\mathrm{x} \geq$ \\
1320
\end{tabular}

Keterangan :

1) satu peserta didik mendapat skor prestasi $\geq 70$

2) tiga peserta didik mendapat skor prestasi masing-masing $\geq 75$

3) tiga peserta didik mendapat skor prestasi masing-masing $\geq 80$ 
4) lima peserta didik mendapat skor prestasi masing-masing $\geq 85$

5) empat peserta didik mendapat skor prestasi $\geq 90$

Skor prestasi peserta didik diperoleh dari penjumlahan dua aspek penilaian sehingga diperoleh skor terendah adalah $\geq 70$ diperoleh satu peserta didik dan skor tertinggi $\geq 90$ diperoleh empat peserta didik. Rata-rata peserta didik memperoleh skor penilaian prestasi sebanyak $\geq 75$ $\geq 80$. Data tersebut diperoleh dari 16 peserta didik.

Tabel 4.6. Penilaian Akhir

\begin{tabular}{|c|c|c|c|}
\hline No & $\begin{array}{c}\text { Skor } \\
\text { penilaian }\end{array}$ & $\begin{array}{ll}\text { Jumlah } \\
\text { siswa }\end{array}$ & Nilai \\
\hline 1 & $\geq 70$ & 1 & $\geq 70$ \\
\hline 2 & $\geq 75$ & 4 & $\geq 300$ \\
\hline 3 & $\geq 80$ & 3 & $\geq 240$ \\
\hline 4 & $\geq 85$ & 4 & $\geq 340$ \\
\hline 5 & $\geq 90$ & 4 & $\geq 360$ \\
\hline & $\sum \times \geq 330$ & n16 & $\begin{array}{c}x \geq \\
1310\end{array}$ \\
\hline
\end{tabular}

Keterangan:

1) satu peserta didik yang mendapat nilai kurang $(\geq 70)$.disebut kurang

2) empat peserta didik mendapat nilai $\geq 75$ disebut cukup, karena sesuai dengan nilai ketuntasan Pelajaran akidah akhlak yaitu $(\geq 75)$.

3) Nilai berpredikat baik antara rentang nilai $\geq 80-\geq 85$, berjumlah tujuh Peserta didik. Tiga Peserta didik mendapat nilai $\geq 80$, empat peserta didik mendapat nilai $\geq 85$,

4) Kriteria predikat sangat baik dengan rentang nilai antara $\geq 90-100$, diperoleh empat orang peserta didik. Mendapat nilai 90 sebagai nilai tertinggi.

5) Jumlah peserta didik yang mengikuti penelitian 16 siswa sesuai dengan jumlah populasi dalam penelitian ini.

Nilai akhir adalah skor pengamatan dijumlahkan dengan skor prestasi dibagi dua. Nilai terrendah 70 diperoleh satu peserta didik dan tertinggi 90 diperoleh empat peserta didik.

\section{Pembahasan secara Kuantitatif}

Pembahasan secara kuantitatif dalam penelitian yang berjudul "implementasi Pembelajaran Berbasis Budaya dalam meningkatkan prestasi belajar siwa pada Mata Pelajaran Akidah Akhlak di kelas V MI NW Lendang Batu priode tahun ajaran 2018/2019", pembahasan penghitungan nilai akhir siswa atau data berupa angka yang didapat dalam penelitian untuk mengetahui.

Dalam penelitian ini, peneliti melakukan penghitungan data kuantitatif dengan menggunakan rumus"rata-rata (mean) merupakan program statistik yang digunakan untuk memudahkan peneliti dalam melakukan penghitungan kuantitatif.

$$
\mathrm{X}=\frac{\sum \mathrm{x}}{\mathrm{n}}
$$

Keterangan:

$$
\begin{aligned}
& \mathrm{X}=\text { Nilai rata-rata } \\
& \begin{array}{l}
\sum \mathrm{x}=\text { Jumlah nilai semua siswa } \\
\mathrm{n}=\text { Jumlah siswa } \\
\qquad \mathrm{X}=\frac{1310}{16} \\
\quad \mathrm{X}=81.8
\end{array}
\end{aligned}
$$

Jadi dapat diketahui bahwa prestasi peserta didik kelas V MI NW Lendang Batu meningkat $(\geq 7,25)$ setelah menggunakan strategi pembelajaran berbasis budaya dalam mata pelajaran Akidah 
Akhlak sub materi bertanggung jawab,adil dan bijaksana. Dengan nilai rata-rata $\geq 81.8$.

Dapat dilihat rumus ketuntasan KKM sebagai berikut :

$$
\begin{aligned}
& \mathrm{P}=\frac{\sum \times}{\mathrm{n}} \times 100 \% \\
& \mathrm{P}=\frac{15}{16} \times 100 \% \\
& \mathrm{P}=97.75 \%
\end{aligned}
$$

Data prestasi siswa sebelum menggunakan pembelajaran berbasis budaya dapat dilihat dalam tabel berikut:

Tabel 4.7. Data prsetasi belajar siswa

\begin{tabular}{|c|c|c|c|}
\hline No & $\begin{array}{c}\text { Skor } \\
\text { penilaian }\end{array}$ & $\begin{array}{c}\text { Jumlah } \\
\text { siswa }\end{array}$ & Nilai \\
\hline 1 & $\geq 65$ & 6 & $\geq 390$ \\
\hline 2 & $\geq 70$ & 3 & $\geq 210$ \\
\hline 3 & $\geq 75$ & 4 & $\geq 300$ \\
\hline 4 & $\geq 80$ & 1 & $\geq 80$ \\
\hline 5 & $\geq 85$ & 1 & $\geq 85$ \\
\hline 6 & $\geq 90$ & 1 & $\geq 90$ \\
\hline & $\sum \times \geq 465$ & $\mathrm{n} 16$ & $\mathrm{x} \geq 1155$ \\
\hline
\end{tabular}

Dan adapun nilai ketuntasan belajar siswa dapat dilihat dalam tabel di bawah.

Tabel 4.8. Data prestasi belajar siswa

\begin{tabular}{|c|c|c|c|c|}
\hline $\begin{array}{l}\mathrm{N} \\
\mathrm{o}\end{array}$ & $\begin{array}{l}\text { Keadaan } \\
\text { siswa }\end{array}$ & $\begin{array}{l}\text { Jumla } \\
\mathrm{h}\end{array}$ & $\begin{array}{l}\text { Persentase } \\
\%\end{array}$ & $\begin{array}{c}\text { Nilai } \\
\text { rata- } \\
\text { rata }\end{array}$ \\
\hline 1 & Tuntas & 7 & $43.75 \%$ & $\begin{array}{c}15.9 \\
3\end{array}$ \\
\hline 2 & $\begin{array}{c}\text { Tidak } \\
\text { tuntas }\end{array}$ & 9 & $56.25 \%$ & $\begin{array}{c}56.2 \\
5\end{array}$ \\
\hline & Jumlah & 16 & $100 \%$ & $\begin{array}{c}72.1 \\
8\end{array}$ \\
\hline
\end{tabular}

Keterangan:

1) Enam peserta didik mendapat skor prestasi $\geq 65$

2) Tiga peserta didik mendapat skor prestasi masing-masing $\geq 70$

3) Empat peserta didik mendapat skor prestasi masing-masing $\geq 75$

4) Satu peserta didik mendapat skor prestasi masing-masing $\geq 80$

5) Satu peserta didik mendapat skor prestasi $\geq 85$

6) Satu peserta didik mendapat skor prestasi $\geq 90$.

Skor prestasi peserta didik diperoleh dari penjumlahan dua aspek penilaian sehingga diperoleh skor terendah adalah $\geq 65$ diperoleh enam peserta didik dan skor tertinggi $\geq 90$ diperoleh satu peserta didik.

Diketahui bahwa sebelum mengguakan pembelajaran berbasis Budaya peneliti mendapat data dari guru Pelajaran Akidah Akhlak sebagai berikut : Dari tabel di atas dapat di lihat dari 16 peserta didik terdapat 7 peserta didik yang tuntas dan 9 peserta didik yang tidak tuntas. Dengan nilai rata-rata 72.18 .ketuntasan belajar peserta didik adalah $43.75 \%$ dan nilai ini masih kurang dari ketuntasan secara klasikal. Siswa yang tidak tuntas disebabkan karena kurangnya motivasi belajar,dan minat belajarnya rendah sehingga diperlukan perbaikan strategi mengajar yang mampu meningkatkan motivasi belajar dan minat belajar peserta didik. 
Jadi dapat diketahui bahwa prestasi peserta didik kelas V MI NW Lendang Batu meningkat $(\geq 75)$ setelah menggunakan strategi pembelajaran berbasis budaya dalam mata pelajaran Akidah Akhlak sub materi bertanggung jawab,adil dan bijaksana. Dengan nilai rata-rata $\geq 81.8$ berarti peserta didik di MI NW Lendang Batu dinyatakan tuntas belajar meningkat dari $34.75 \%$ sebelum pembelajaran berbasis Budaya menjadi 97.75\% setelah menggunakan pembelajaran berbasis budaya berhasil. Hal ini karena pembelajaran berbasis budaya merupakan pendekatan pembelajaran yang cocok diterapkan dalam mata pelajaran Akidah Akhlak.

Pembelajaran berbasis budaya dalam pembelajaran Akidah Akhlak dapat meningkatkan prestasi belajar peserta didik dan menambah wawasan peserta didik mengenai Agama Islam serta sikap bertanggung jawab, adil dan bijaksana, memiliki dan mencintai agama sehingga siswa tertarik dari diri sendiri untuk melestarikan sikap bertanggung jawab, adil, dan bijaksana dalam kehidupan sehari-hari.

\section{SIMPULAN}

Setelah selesai melaksanakan penelitian dengan menggunakan pendekatan pembelajaran berbasis budaya pada mata pelajaran Akidah Akhlak materi meng- gambar kalikatur sifat bertanggung jawab, adil dan bijaksana pada siswa kelas $\mathrm{V}$ tahun pelajaran 2018/2019 diperoleh hasil bahwa dengan menggunakan pendekatan pembelajaran berbasis budaya mampu meningkatkan prestasi peserta didik dengan baik dan signifikan dalam pembelajaran Akdah Akhlak, keaktifan siswa dalam proses belajarpun ditunjukan dengan motivasi yang tinggi dalam mengikuti pembelajaran.

Pembelajaran berbasis budaya juga mengajarkan kepada peserta didik untuk semakin mengenal Aklak terpuji tentang sifat-sifat tanggung jawab, adil dan bijaksana sehingga muncul dengan sendirinya rasa untuk melestarikannya dalam kehidupan sehari- hari.

\section{DAFTAR PUSTAKA}

Bungin, H. M Burhan. 2005. Metodelagi Penelitian Kuantitatif. Jakarta: Kencana.

Fatah, Yasin. 2008. Dimendi-Dimensi Pendidikan Islam. Malang: UIN Malang Press.

Hatimah Ihat, dkk. 2007. Pembelajaran Berwawasan Kemasyarakatan. Jakarta : Bumi Aksara.

Hamalik, Oemar. 2009. Psikologi Belajar \& Mengajar. Bandung : Bumi Aksara.

Hamalik, Oemar. 2010. Kurikulum dan Pembelajaran. Jakarta : Bumi Aksara.

Jamarah Saiful, Bahri. 2002. Strategi 
belajar mengajar. Jakarta: Renika Cipta.

Mulyasa E. 2006. Menjadi Guru Profesional. Bandung : PT. Remaja Rosdakarya.

Nasution. 2005. Teknologi Pendidikan Jakarta : PT Bumi Aksara.

Punaji H. Setyosari. 2010. Metode penelitian pendidikan dan pengembangan. Jakarta: Kencana Prenada Media Group.

Purwanto, Ngalim. 2007. Fsiolgi Pendidikan. Jakarta: PT remaja Rosdakarya.

Purwanto M, Ngalim. 2002. Ilmu Pendidikan teoritis dan praktis. Jakarta: Remaja Rosdakarya.

Sanjaya, Wina. 2007. Strategi Pembelajaran Berorientasi Standar Proses Pendidikan. Jakarta: Kencana.

Sardiman. 2007. Interaksi Dan Motivasi Belajar Mengajar. Jakarta: PT Raja Grafindo Persada.

Sugiyono. 2008. Metode Penelitian Kuantitatif, Kualitatif, dan $R \& D$. Bandung: Alfabeta.

Suprayekti, dkk. 2008. Pembaharuan Pembelajaran di SD. Jakarta : PT Raja Grafindo Persada. 